\title{
Quality of Science Teachers Produced from Colleges of Education in Plateau State: Implication for Science Education
}

\author{
Anthonia C. Chukwu \\ Chemistry Department \\ Federal College of Education, Pankshin-Nigeria
}

\section{Doi:10.5901/jesr.2013.v3n8p137}

\begin{abstract}
The onus of laying the foundation for scientific literacy lies on the NCE science teachers according to the national policy on education. The paper set out to determine the quality of N.C.E science teachers produced from colleges of education in Plateau state. Student's results were used as well as a peer reviewed questionnaire. 120 respondents participated in the research. Analysis of the data using mean and percentages revealed that not less than $30 \%$ of the students carry over courses every year. $62.5 \%$ of the respondents stated that it is becoming difficult to teach the N.C.E students. Poor background of students from secondary school and poor communication skill are some of the problem faced by the teacher trainers. It was recommended that only high quality students should be admitted into the programme.
\end{abstract}

\section{Introduction}

The importance of science and technology to any nation is no longer in doubt hence nations the world over are emphasizing the study of science and technology in schools. In Nigeria, science is taught from primary school level to the higher education level. The importance attached to science education is so much that non-science students in Nigeria are made to learn some science in their general studies courses.

Other efforts made by the nation can also be seen in the admission policy which states that $60 \%$ of the candidates admitted into higher institutions should be for science and technology courses. In addition, there are schools and even universities established mainly for science and technology courses with the aim of taking the nation higher in science and technology. In Nigeria today, there are many schools, universities and colleges of education. Some are owned by individuals and organizations. They offer admission to students to study various courses including science courses. Thus there are many students graduating from these institutions. Education has thus grown quantitatively but the quality of our education has some question marks. Some researchers have expressed doubts about the products from our schools. Akpan (2001) stated that products from our school system have been found wanting in all the parameters used to assess them. Ajewole (2005) observed that students' achievement scores often fall below international standard; implying that their knowledge and understanding of science do not meet the standard for competence in the global market.

There has also been a persistent cry about the performance of students in science and technology over the years (Oyedokun 2002 and Chukwu 2010). This is manifested in the low percentage of students who make the required credits at the school certificate examination. Some research findings also show that pre-service as well as practicing teachers lack proper understanding of some science concepts (Ngoka1989; Jimo 2002 and Chukwu 2010).

The poor performance of the students has been attributed to unavailability of human and material resources such as qualified teachers, well equipped laboratories as well as the conceptual demands of science and the students background knowledge among other causes (Gyuse, 1990; 
Akano, and Akpokiere, 2006 \& Chukwu 2010).

The search light should also beam on the teachers especially teacher preparation. This is because no educational system can rise above the level of its teachers. To ensure effective science and technology education in our schools, highly qualified and competent teachers are required. Agreeing to this, Ameh (1987) states that for effective science teaching in our schools, science teachers with knowledge of the subject matter and confidence to teach the concepts effectively are required. Akale (1992) on his part points out that one of the problems of science curriculum development efforts is the non recognition that the teacher is the key factor in determining the quality and success of its implementation. The implication of these statements is that for the nation to develop in science and technology, competent and effective science teachers are required. In Nigeria, science teachers are produced in colleges of education and faculties of education in universities. Students from colleges of education obtain the Nigerian Certificate in Education which qualifies them to teach science in primary and junior secondary schools according to the national policy on education. In practice however, the N.C.E science teachers are also teaching at the senior secondary school level (Chukwu \& Chukwu 2013). Thus they are involved in preparing students for senior secondary school certificate examination. The question one should ask is. How are these N.C.E science teachers prepared? What is the quality of science teachers being produced in the colleges of education? What calibre of students are admitted to be trained as science teachers. Chukwu and Chukwu (2008) stated that the problem of teacher education is the caliber of students admitted into the N.C.E programme. For Dike and Ndokwu(2007:20)

...the increase in the nations population led to a corresponding increase on the quest for education. The interplay of economics and politics as they affect education and teacher education and training in particular led to some degree of compromise of admission requirement. Consequently, a large proportion of what we have today as trained teachers' are academically and professionally incompetent.

This is a very ugly trend because the onus of inculcating the scientific skills lies on the science teacher. Where the teacher lacks the competence, the nation will not advance scientifically. Though there is improvement on the admission requirement; that is all candidates seeking admission into higher institutions are required to have five credits including English and Mathematics. The problem has not been solved.

The N.C.E programme is very important because the products are not only to teach at the primary and junior secondary schools but also act as feed stock for the faculty of education in the universities. They also lay the foundation for science teaching in the secondary schools. This makes their position more important because even those who may not pursue science courses in future need the basic science knowledge. The world today needs individuals who are scientifically literate so that they can participate effectively in science based societal issues and understand their environment. Olorukooba (2007) observed that this can only be achieved with better programme oriented towards teacher preparation and professional development.

What is observed in our colleges of education now in fact leaves much to be desired. Chukwu, Gambo and Ibejekwe (2013) showed that N.C.E science students are not performing very well as expected of them. If the students are not doing well in school, what will be their output when they go into the field for one cannot give what he/she does not have? The hands of the teacher trainers seem to be full because of the crowded class making it difficult for them to give individualized instruction or carry out practicals effectively.

Many students are being admitted into colleges of education to study science but little attention is paid on the quality of the products. There are certain qualities expected of a good teacher and invariably a good science teacher. A good teacher is expected to be firm, humorous, loving, kind, patient, have good knowledge of the subject matter, have effective discipline skills, have good communication skills etc. All these qualities are of importance but this paper is 
concerned mainly with the knowledge of the subject matter. This is because everything that happens in a classroom centres on the subject matter. All the teacher is doing in the class is to make his/her students to understand the subject matter. If Nigeria is to advance in science and technology, more attention should be paid on the quality of science teachers from our colleges of education and not the quantity. The efforts made to better the educational system should be in the right direction which is teacher preparation. Since the N.C.E science teachers are the ones to lay the foundations for science education and knowledge generally, their preparation is of utmost importance. This paper therefore tried to determine the quality of science teachers produced from colleges of education in Plateau State.

\section{Research Questions}

The following questions were raised to guide the research.

1. What is the performance of the science students in colleges of education in Plateau State?

2. What is the perception of the teacher trainers about the quality of the science teachers graduating from their departments?

3. What are the challenges faced by the teacher trainers in producing high quality NCE science teachers?

\section{Methodology}

The population for the study is 160 science teachers in the two colleges of education in Plateau State ie College of Education Gindiri and Federal College of Education Pankshin. Out of this only 120 participated in the study. Effort was made to reach all but it was not possible. The instruments for the data collection were the students' results and a questionnaire. The result used was that of NCE 111 students from both colleges for four years. These calibre of students have gone through the programmes of the colleges including teaching practice. The questionnaire was divided into two sections. Section A sought information about the perceived quality of the science teachers in training while section $B$ is a five point Likert Scale on the factors militating against effective teaching on the part of the teacher trainers. Data collected was analyzed using means and percentages. For security reasons, the colleges are represented with A and B.

\section{Anaysis of Data}

4.1 Research question one: What is the performance of the science students in colleges of education in Plateau State?

Table 1: Performance of students in first semester in 2007/08 - 2009/10 and 2011/2012

\begin{tabular}{lcccccccc}
\hline & $2007 / 2008$ & \multicolumn{2}{c}{$2008 / 2009$} & $2009 / 2010$ & \multicolumn{2}{c}{$2011 / 2012$} \\
& A & B & A & B & A & B & A & B \\
\hline Total number of students & 141 & 255 & 195 & 270 & 323 & 320 & 212 & 400 \\
No. without carry over & 65 & 150 & 62 & 170 & 93 & 223 & 77 & 249 \\
Percentage(\%) & 46 & 58.8 & 31.8 & 63.9 & 28.8 & 69.7 & 36.3 & 62.3 \\
No. with carry over & 76 & 105 & 133 & 100 & 230 & 97 & 135 & 151 \\
Percentage(\%) & 53.9 & 41.2 & 68.2 & 37.0 & 71.2 & 30.3 & 63.7 & 37.7 \\
\hline
\end{tabular}


Table 2: Performance of students in second semester in 2007/08 - 2009/10 and 2011/2012

\begin{tabular}{lcccccccc}
\hline & $2007 / 2008$ & \multicolumn{2}{c}{$2008 / 2009$} & \multicolumn{2}{c}{$2009 / 2010$} & \multicolumn{2}{c}{$2011 / 2012$} \\
& A & B & A & B & A & B & A & B \\
\hline Total number of students & 146 & 240 & 199 & 261 & 325 & 297 & 215 & 382 \\
No. without carry over & 68 & 160 & 69 & 176 & 117 & 200 & 87 & 209 \\
Percentage (\%) & 46.6 & 66.7 & 34.7 & 67.4 & 36 & 67.3 & 40.5 & 54.7 \\
No. with carry over & 78 & 80 & 130 & 85 & 208 & 97 & 128 & 173 \\
Percentage (\%) & 53.3 & 33.3 & 65.3 & 32.6 & 64.0 & 32.7 & 59.5 & 45.3 \\
\hline
\end{tabular}

Tables 1 and 2 show that not less than 30\% of the students carry over courses. The percentage is even as high as $68.2 \%$. This is not an encouraging observation.

4.2 Research question two: What is the perception of the teacher trainers about the quality of the science teachers graduating from their departments?

Table 3: Perception of teachers about students graduating from their departments.

\begin{tabular}{lcc}
\hline & No. of Respondents & Percentage $(\%)$ \\
\hline Excellent & 0 & 0 \\
Very good & 27 & 22.5 \\
Average & 63 & 52.5 \\
Poor & 30 & 25.0 \\
Very poor & 0 & 0 \\
\hline
\end{tabular}

Table 3 shows that $52,5 \%$ of the respondents graded the students graduating from their departments as just average while $25.5 \%$ graded them as poor. None graded them as excellent or very poor.

Table 4: Trend of the quality of the students over the years in terms of academic performance.

\begin{tabular}{lcc}
\hline \multicolumn{1}{c}{ Item } & No. of Respondents & Percentage (\%) \\
\hline Performance has been impressive & 20 & 16.7 \\
There has been no change & 10 & 08.3 \\
The students are good; they learn fast & 15 & 12.5 \\
It is becoming increasingly difficult to teach the students & 75 & 62.5 \\
\hline
\end{tabular}

Table 4 shows that $62.5 \%$ of the respondents find it difficult to teach the students while $16.7 \%$ feel that the student $\mathrm{s}$ are doing very well.

Table 5: Response to assignment by students

\begin{tabular}{lcc}
\hline \multicolumn{1}{c}{ Item } & No. of Respondents & Percentage (\%) \\
\hline The students do independent work & 6 & 05 \\
The students copy from one another. & 81 & 67.5 \\
The students submit assignment promptly & 12 & 10 \\
The students do not do the assignment as required. & 21 & 17.5 \\
\hline
\end{tabular}

Table 5 shows that $67.5 \%$ of the respondents observe that the students copy answers to assignment from one another instead of making efforts to do the assignment themselves. Copying defeats the aim of the assignments. 
Table 6. Students response to examination or test questions.

\begin{tabular}{lcc}
\hline \multicolumn{1}{c}{ Item } & $\begin{array}{c}\text { No. of } \\
\text { Respondents }\end{array}$ & $\begin{array}{c}\text { Percentage } \\
(\%)\end{array}$ \\
\hline $\begin{array}{l}\text { Students response to questions is encouraging showing high } \\
\text { mastery of the subject matter }\end{array}$ & 20 & 16.7 \\
$\begin{array}{l}\text { Students response to question only shows only faint } \\
\text { understanding of the subject matter }\end{array}$ & 82 & 68.3 \\
$\begin{array}{l}\text { Students response to question indicates that either they were } \\
\text { not taught or they did not understand the subject matter. }\end{array}$ & 18 & 15 \\
\hline
\end{tabular}

Table 6 shows that $68.3 \%$ of the respondents observe that students' response to questions only shows faint understanding of the subject matter. Tables 3, 4, 5 and 6 show that the teacher trainers perception of the students is not encouraging. To them, they are of low quality.

4.3 Research question 3: What are the challenges faced by the teacher trainers in producing high quality NCE science teachers? Table 7: Factors militating against production of high quality science teachers

\begin{tabular}{lc}
\hline \multicolumn{1}{c}{ Item } & Mean \\
\hline Poor communication skill & 4.30 \\
Poor background from secondary school & 4.68 \\
Inability to understand the subject & 4.12 \\
Lack of commitment to their studies & 4.48 \\
Crowded programme on the part of the teachers & 3.87 \\
Incessant strike actions & 3.1 \\
Inadequate teaching materials/ equipment & 3.7 \\
Inadequate facilities/classroom & 3.8 \\
High population of students in class & 3.6 \\
\hline
\end{tabular}

Table7. Shows that the teachers see poor background of the students from the secondary school as the greatest challenge they face in the course of training the students followed by lack of commitment on the part of the students then poor communication skill while incessant strike had the least mean of 3.1. All the nine items were seen as factors militating against the production of high quality science teacher.

\section{Discussion}

It has been stated that the teacher is the bedrock of every educational system and that no teacher can give what he does not have. This being the case, the quality of the teachers produced to teach science in Nigerian schools leaves much to be desired. Tables 1 and 2 show that not less than30\% of the students carry over courses. The implication is that the students are not performing well. It is important to note that these students made credits at the senior school certificate examination (SSCE) before admissions were offered to them and the examinations written are teacher made tests. Chukwu, Gambo and Ibejekwe (2013) from their study showed that the NCE Science students are not performing well in their examinations. This carrying over of courses has cost implication as well as work load for the teachers. The students too will end up spending more years in the colleges before graduation or end up not graduating at all.

Table 3 shows that $52.5 \%$ and $25 \%$ of the teachers perceive the students as average and poor academically respectively. In the same vain, $62.5 \%$ say that it is becoming increasingly difficult to teach the students. One can only imagine what kind of science teachers this caliber of students will be when they go into the field. No wonder Dike and Ndokwo (2007) states that "What 
we have as trained teachers are academically and professionally incompetent" In Table 4, 67.5\% the respondents stated that the students copy from one another when assignments are given to them. This is disheartening it means that the students do not know what they are doing. If a student teacher cannot seek for information, read it and reproduce it at his own time in order to do an assignment how will he/she be able to prepare his/her lessons when he/she is in the field more so when he/she may have to teach topics that he was not taught while in school. Copying is examination malpractice it appears that the students do not know this. Chukwu, Gambo and I bejekwe (2013) found that some students in our higher institutions no longer know activities that constitute examination malpractice. If the student teachers do not know that copying is wrong how will they inculcate that in their students.

In Table 6, 68.3\% indicated that students response to questions show only faint understanding of the subject matter. This is a clear indication that the students being trained as science teachers find it difficult to understanding the subject matter. This result is expected since they cannot task themselves to do assignments when it is given to them; how will they learn or improve themselves. Table 7 shows that the lectures are really having hard time producing high quality science teachers. Poor background from secondary school, poor communication skills had very high means over 4 . Relating this to all the tables, it is like a case of garbage in garbage out. But should this be in education? Chukwu and Chukwu (2008) had stated that the problem of teacher education is the admission policy. Though the new admission policy is that all candidates seeking admission into higher institutions must have five credits including English and Mathematics, discrepancy still exists. Those who score high marks go to the universities while those with low scores are sent to colleges of education for the teachers trainer to perform miracles and turn them into wonderful teachers. The government seems to be paying lip service to their desire to become technologically advanced. I magine that the cut off point for colleges of education for this year 2013 was reduced to 150 and the reason advanced is to give more people opportunity to gain admission into higher institutions. Is the government interested in people just going through science programme and still remain scientifically illiterate (Ajewole 2005) or to build a scientifically literate nation. The poor back ground of the students could be because the teachers preparing them are not competent too. Thus it is a case of a viscous circle. This must stop. It is high time the nation calls a spade a spade. NCE teachers must be properly trained because they lay the foundation for our educational system.

\section{Conclusion}

The N.C.E science teachers according to the national policy on education are to teach at the primary school and junior secondary school. So the onus of laying the foundation for scientific literacy lies on them. The paper has revealed that the quality of N.C.E science teachers being produced from the colleges in Plateau State is nothing to write home about. Teacher education should not be taking for granted or looked at as a dumping ground where those who could not gain admission in other courses should be admitted. It is important to note that a small mistake made by a teacher can destroy the dreams of a whole generation

\section{Recommendtion}

1. Attention should be paid to the secondary education where the education foundation is laid

2. Tertiary educations are not a basic education $d / 4$ only those who can benefit from it should be given the opportunity to go through it.

3. High quality students should be admitted into the programme if any desired change is to be made. 
4. The government should make a conscious effort to attract good and highly qualified students into the programme.

5. Serious efforts should be made to teach the students the language of instruction at the primary and secondary school for effective communication.

\section{References}

Ajewole, A. G. (2005). Science and technology education in secondary schools: need for manpower development. Journal of the Science Teachers Association of Nigeria 40(1\&2), 63-67.

Akale, M. A. (1992). Integrated science programme constraints and prospects in Nigerian schools. The Nigerian Teacher Today, 37 (40), 178-180.

Akano, B. U. and Akpokiere, R. (2006). The status of human and material resources for teaching the basic sciences in colleges of education in Niger State. In U. Nzenwi (Ed.), $47^{\text {th }}$ Annual Conference Proceedings of the Science Teachers Association of Nigeria.27- 32

Akpan, E. U. U. (2001). Government and science and technology education in Nigeria. Journal of Educational Issues, 1 (1), 101-113.

Ameh, C. O. (1987). A study of science teachers' concept in Nigeria. (Ph.D. Dissertation, Monash University.1987).

Chukwu, A. C. (2010). Cognitive factors as predictors of performance in some chemistry concepts among college of education students in Plateau State. ( Ph.D. Dissertation, University of J 0s.2010)

Chukwu, A. C. \& Chukwu, U. P. (2008). Admission requirement: the problem of chemistry teacher education. Journal of educational Issues 3(2), 20-26.

Chukwu, A. C. \& Chukwu, U. P. (2010). A survey of the qualification of science teachers in Pankshin District of Plateau State. Internal Journal of African Studies and Education. 123-129.

Chukwu, A. C., Gambo, N. N. \& Ibejekwe, S. (2013). Examination malpractice among science students in colleges of education in Plateau State. A paper presented at conference of science teachers association of Nigeria (Plateau State Chapter) held at F.C.E Pankshin from3rd to $6^{\text {th }}$ J uly 2013.

Dike, N. \& Ndokwo, K. J (2007). Issues on human resources development for science, technology and mathematics. In U. Nzenwi (Ed.), $48^{\text {th }}$ Annual Conference Proceedings of the Science Teachers Association of Nigeria.19-23

Gyuse, E. Y. (1990). Cognitive development of senior secondary school students in relation to the conceptual demands on their chemistry curriculum. ( Ph.D. Dissertation, University of J os.1990).

Ngoka, G. N. (1989). The cognitive competence and teaching ability of B.Sc (Chem/Ed) chemistry teachers in Nigerian secondary schools. Review of Education, 2, 57-67.

Olorukooba, S. B. (2007). Science and mathematics (STM) education for all students: Promoting effective teaching of STM subjects in our schools through teacher preparation. In U. Nzenwi (Ed.), $48^{\text {th }}$ Annual Conference Proceedings of the Science Teachers Association of Nigeria.3-7

Oyedokun, M. R. (2002). Identification of difficult topics in the senior secondary school certificate biology syllabus as perceived by students. The Nigerian Teacher Today, 10 (1), 110-120. 
